\title{
THE RESPONSE OF THE ALBANIAN COMPETITION AUTHORITY TO THE COVID-19 CRISIS
}

\author{
Jonida Rystemaj, PhD \\ Faculty of Law, University of Tirana \\ Rruga Milto Tutulani, Tirana, Albania \\ jonida.rystemaj@fdut.edu.al
}

\author{
Eniana Qarri, PhD \\ Faculty of Law, University of Tirana \\ Rruga Milto Tutulani, Tirana, Albania \\ eniana.qarri@fdut.edu.al
}

\begin{abstract}
The outbreak of COVID-19 pandemic was a shock for the global economy. It affected almost every country, but certainly in developing countries its impact was harder. The immediate effect was the shortage of several medical and paramedical equipment which were necessary to prevent the virus spread. This shortage was felt in Albanian markets as well and was rapidly followed by a sharp increase of prices in paramedical products. The consumers suffered the highly increased prices amongst fear that in absence of these products, their life was threatened. This behaviour of the market participants was considered suspicious by the Competition Authority which decided to initiate a preliminary investigation to find out whether this behaviour was abusive, or it normally reflected the sudden shortage and the state of emergency. The instigation of this procedure was based on several complaints reported in the media and complaints directly submitted by consumers to the Competition Authority. At the first glance, the traders were exploiting the health emergency to maximise their profits. Subsequently, the Competition Authority (CA) decided to apply some preliminary measures on the wholesale market operators. Furthermore, the CA intervened even in a case of a company in dominant position which was furnishing selected pharmacies. These interventions aimed at restoring somehow the distorted competition in paramedical and medical products.
\end{abstract}

This article will try to shed light on the current market situation and on the effectiveness of the interventions of the CA. How should the Competition Authority behave to restore the distorted competition? Are the current introduced measures enough to help all market participants overcome this state of health emergency? These questions and other issues related with the peculiar situation will be addressed in the current article. The article will be organized as follows: First, a glimpse of the regulation of Albanian competition law will be given. Second, the situation under COVID-19 emergency will be elaborated taking into consideration the guidelines of 
Communication of the Commission on "Temporary Framework for assessing antitrust issues related to business cooperation in response to situations of urgency stemming from the current COVID-19 outbreak" (2020/C 116 I/02). Lastly, the evaluation of the measures introduced by the Competition authority will be analysed and recommendations will be provided.

Keywords: health emergency, competition, distorted competition, COVID-19 pandemic.

\section{INTRODUCTIONS}

The outbreak of COVID-19 pandemic was a shock for the global economy. It affected almost every country, but certainly in developing countries its impact was harder. The immediate effect was the shortage of several medical and paramedical equipment which were necessary to limit the expansion of the pandemic. This shortage was felt in Albanian markets as well and was swiftly followed by a sharp increase in prices of paramedical products. The consumers suffered the highly increased prices amongst fear that in absence of these products their life was threatened.

This article will try to shed light on the current market situation and on the effectiveness of the intervention of the Competition Authority and the government. How should the Competition Authority behave to restore the distorted competition? Are the introduced measures enough to help all market participants overcome this state of health emergency? These questions and other issues related with the peculiar situation will be addressed in the current article.

The article will be organized as follows: First, a glimpse of the regulation of Albanian competition law will be given. Second, the situation under COVID-19 emergency will be elaborated taking into consideration the guidelines of Communication of the Commission on "Temporary Framework for assessing antitrust issues related to business cooperation in response to situations of urgency stemming from the current COVID-19 outbreak". ${ }^{1}$ Lastly, the evaluation of the measures introduced by the Competition authority will be analysed and recommendations will be provided.

The finalization of this article faced few challenges. First, it was the absence of decided cases from the Albanian Competition Authority (ACA), because as we will explain further on, they are still pending. Second, it was the lack of literature that addresses this specific topic. Notwithstanding the lack of specific, topic-related sources the authors will make the pertinent efforts to ensure the highest academic standards of this article.

1 Temporary Framework for assessing antitrust issues related to business cooperation in response to situations of urgency stemming from the current COVID-19 outbreak [2020/C 116 I/02] OJ C 116I, 8.4.2020, pp. 7-10. 


\section{THE CHARACTERISTICS OF ALBANIAN COMPETITION LAW}

Albanian competition law is a relatively new piece of legislation. The first act that was enacted to introduce rules to impose restrictions on the market operators dates back to $1995 .{ }^{2}$ Before 1995 there were no provisions specifically dedicated

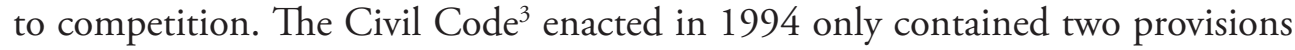
related to unfair competition but in the framework of intellectual property. These provisions foresaw the obligation of any entity not to use the intellectual property of another party and not to use means directly or indirectly against the principle of fairness to the detriment of the other party. Any behaviour in breach of these principles would give rise to damages for the injured party. ${ }^{4}$

Obviously, more detailed, and accurate competition rules were needed to address the whole variety of behaviours that distorted competition. Therefore, in 1995 the law "On Competition" was enacted but was soon repealed in 2003 because it was not fully aligned with the European standards. It did not create any independent authority, rather it created a special directory within the Ministry responsible for commerce to deal with competition cases. ${ }^{5}$ Anyhow, it contained the very first regulation that disciplined market competitors' behaviour to preserve competition.

Since it was not a piece of legislation aligned with the acquis it was quickly repealed by the law no. 9121, dated 28.7.2003 "On the Protection of Competition", as amended subsequently.

This act and the sublegal acts enacted to supplement it have enshrined the European Union legislation and the ample jurisprudence of the Court of Justice of the European Union. Upon entrance into force, this act has had minor amendments that were deemed necessary to keep the law up to date with the changes and developments of the acquis. ${ }^{6}$

For the first time, under this regulation, the ACA was established as an independent body to oversee the compliance with the law requirements. ${ }^{7}$ According to this

Law no. 8044, dated 7.12.1995 “On Competition”, Official Journal No. 27/1995.

3 Civil Code, Law no. 7850, dated 29.7.1994, articles 638 and 639, Official Journal No. $11,12,13,14 / 1994$, as amended.

4 Civil Code, Law no. 7850, dated 29.7.1994, as amended, article 639, Official Journal No. $11,12,13,14 / 1994$.

5 Article 57, Law no. 8044, dated 7.12.1995 “On Competition”, Official Journal No. 27/1995.

6 Malltezi, A., Rystemaj, J., Pelinku, L., Aspekte të së Drejtës së Biznesit në Shqipëri, Tiranë, Mediaprint, 2013.

7 Article 18, Act no. 9121, dated 28.7.2003, Official Journal No. 71/2003. The Competition Authority started to operate on 1.3.2004. Annual Report of the Competition Authority, 2006, p. 6, [report shqip_ndarje ngjyre.indd (caa.gov.al)], Accessed 9 March 2021. 
act, the members of the commission of the ACA are elected from the Parliament as a sign of their independence. ${ }^{8}$

The ACA has had an increased activity over the years ${ }^{9}$ and it has mainly dealt with banking, energy, telecommunication, public procurement markets, etc. ${ }^{10}$ The pharmaceutical market was listed as a priority for the 2020 as to anticipate the developments that this year would reserve for the whole humanity and especially the developments in the pharmaceutical market and health sector. The attention towards this market was linked with the direct effect that it had to the consumers' wellbeing. ${ }^{11}$

Before the onset of the pandemic the pharmaceutical market has had a very limited attention form the ACA. Only few cases regarding distorted competition in pharmaceutical market were dealt by the ACA.

\section{THE ONSET OF THE PANDEMIC AND ITS EFFECT ON COMPETITION}

It has been more than a year now since the coronavirus pandemic emerged threatening the health of people and economies of countries. In Albania, the first confirmed case was recorded on 9 March $2020^{12}$ followed immediately by a very strict lockdown that aimed at preventing the transmission chain. ${ }^{13}$

The lockdown was not easy either for the psychological health of the citizens or the economy. Anyhow, it was deemed the appropriate measure to protect public health. The lockdown was imposed through a normative act which set forth the restrictions taking place and imposed fines in case of breaching these rules. Besides halting any public gathering or organization of public events ${ }^{14}$ the normative act also regulated few issues regarding competition. It impeded the normal trade flow and stopped the exportation of medications and medical supplies. ${ }^{15}$ This was a protectionist measure to preserve any medical supply that might have been needed in the "war" against the virus.

8 Article 21(1), Law no. 9121, dated 28.7.2003, as amended, Official Journal No. 71/2003.

9 Annual Report of the Competition Authority, 2019, [Raporti-Vjetor-2019.pdf (caa.gov.al)], Accessed 8 March 2021.

$10 \quad$ Ibid., p. 11, [Raporti-Vjetor-2019.pdf (caa.gov.al)], Accessed 8 March 2021.

11 Ibid., p. 11, [Raporti-Vjetor-2019.pdf (caa.gov.al)], Accessed 9 March 2021.

12 Albania: Health officials confirm first cases of COVID-19 March 9 [garda.com], Accessed 9 March 2021.

13 This was imposed through the Normative Act no. 3, dated 15.3.2020, Official Journal No. 37/2020.

14 Very high fines were foreseen for the wrongdoers under the Normative Act.

15 Article 3(1) of the Normative Act no. 3, dated 15.3.2020, Official Journal No. 37/2020. 
Another provision with direct effect in competition, especially aiming at consumer protection was sanctioning any entity which set higher prices for medications, medical supplies, and services. The sanction was rather considerable because any wrongdoer was charged with a fine of 5.000.000 ALL (Albanian Lek) (approximately 40.000 Euros) and in case the behaviour was repetitive this sanction was accompanied by a closure of the business for 6 months. ${ }^{16}$ The price was deemed to be increased if compared to the previous year, it was higher and not imposed by the importer. ${ }^{17}$

Apparently, the new reality now was dictated by the course of the pandemic. The market was not in a normal situation and consequently normal competition rules may not be applied, especially in the health sector. That was the reason the normative act stipulated for private health institutions to provide all the necessary support to public health institutions, if that was needed, and was ordered by the Minister responsible for health. ${ }^{18}$ The focus of these measures, introduced by the government, gravitated towards the protection of consumers' health and rights.

Similar approaches were followed by several competition authorities in other countries $^{19}$ and the ECN which stated that "it is of utmost importance to ensure that products considered essential to protect the health of consumers in the current situation (e.g. face masks and sanitising gel) remain available at competitive prices." 20 Also, the Competition and Market Authority in UK explicitly stated that "... the CMA's work should be focussed on what matters most to consumers." ${ }^{21}$ Furthermore, the guidelines listed the allowed cooperation between businesses within the pandemic context emphasising that this was not "a free pass" for business. ${ }^{22}$ As regards the essential products the CMA noted "It is of the utmost importance to ensure that the prices of products or services considered essential to protect the health of consumers in the current situation (for example, face masks and sanitising gel) are not artificially inflated by unscrupulous businesses seeking to take

\footnotetext{
$\overline{16}$ Article 3(12), Ibid.

17 Article 3(12), Ibid.

18 Article 3(16), Ibid.

19 CMA approach to business cooperation in response to coronavirus (COVID-19) [www.gov.uk], Accessed 13 April 2021.

20 Antitrust: Joint statement by the European Competition Network (ECN) on application of competition law during the Corona crisis [202003_joint-statement_ecn_corona-crisis.pdf (europa.eu)], Accessed 13 April 2021.

21 CMA approach to business cooperation in response to coronavirus (COVID-19), [CMA approach to business cooperation in response to coronavirus (COVID-19) - GOV.UK (www.gov.uk)], Accessed 13 April 2021.

22 Ibid.
} 
advantage of the current situation by colluding to keep prices high or, if they have a dominant position in a market, by unilaterally exploiting that position." ${ }^{23}$

Amid the pandemic, the competition law faced two major challenges: the first was consumer protection and the second was to ensure flexibility for undertakings that might engage in a closer cooperation due to the crisis. In these circumstances, as the Communication from the Commission has noted "it is more important than ever that undertakings and consumers receive protection under competition law". ${ }^{24}$

\section{THE INTERVENTION OF THE COMPETITION AUTHORITY}

Immediately after these developments, the Albanian market reflected a shortage of paramedical equipment which were necessary in safeguarding health. This shortage was subsequently followed by a sharp increase in prices of these essential products which were considered to have vital importance for health protection. This behaviour of the market participants was considered suspicious by the Competition Authority which instantly decided to initiate a preliminary investigation to find out whether this behaviour was abusive, or it normally reflected the sudden shortage and the state of emergency. The main driver of the ACA was the consumers' wellbeing, especially in a peculiar situation as the COVID-19 outbreak. ${ }^{25}$ The instigation of this procedure was based on several complaints reported in the media and complaints directly submitted by consumers who noticed a shortage in the retail market of paramedical products (such as disinfectant gels, alcohol, and face masks) and a rapid and unjustifiable increase of the prices of these products. ${ }^{26}$ The preliminary investigation lasted until $15.10 .2020^{27}$ when the ACA decided to start the in-depth investigation procedure against these companies which was planned to last six months as of this announcement.

The ACA immediately after announcing the initiation of the preliminary procedure in the paramedical supply market, to preserve competition and to avoid any irreparable damage, decided to stop undertakings in this relevant market to

23 CMA approach to business cooperation in response to coronavirus (COVID-19) [CMA approach to business cooperation in response to coronavirus (COVID-19) - GOV.UK (www.gov.uk)], Accessed 13 April 2021.

24 Temporary Framework for assessing antitrust issues related to business cooperation in response to situations of urgency stemming from the current COVID-19 outbreak (2020/C 116 I/02), OJ 116I, 8.4.2020, pp. 7-10.

25 Decision no. 684, dated 18.3.2020 of the Commission of the CA.

26 Decision no. 685, dated 18.3.2020 of the Commission of the CA.

27 Decision no. 716, dated 15.10.2020 of the Commission of the CA. 
impose unjust prices directly or indirectly. It also ordered them to comply with the transparency requirements as regards prices of paramedical products and to apply cost-oriented prices. ${ }^{28}$ The ACA called all the undertakings in the relevant market to be transparent when setting prices for the paramedical products and to publish them in their websites or other communication channels. ${ }^{29}$ Apparently, this pandemic served as an opportunity to use a legal tool, such as interim measures, that have been used infrequently. ${ }^{30}$ In this case, the application of this interim measures fulfilled both criteria: the prima facie infringement of competition and urgency. However, it is surprising that the ACA, despite setting the 6-month deadline to finish the in-depth investigation (of a case that prima facie was an infringement but had not the certainty for a final decision), while this presentation was being written no report and/or decision from the ACA was published.

These temporary measures (that had effect only during the investigation period ${ }^{31}$ ) were disregarded by some of the undertakings operating in the market. Thus, the ACA intervened and with the decision no. 717 , dated 15.10 .2020 by fining many undertakings ${ }^{32}$ which during February-May 2020 continued to unjustifiably increase the prices of the paramedical products (face masks, alcohol, and disinfectant gels). ${ }^{33}$

Again, the ACA intervened in another case which is, even though not directly, linked with the pandemic. The ACA imposed an interim measure to one of the pharmaceutical undertaking which was the only one importing the flu vaccine INFLUVAC SUB-UNIT TETRA, Suspension for injection $\mathrm{x}(15 \mathrm{mcg} H A+15 \mathrm{mcg}$ HA $+15 \mathrm{mcg} H A+15 \mathrm{mcg} H A) / 0.5 \mathrm{ml}$, Box x 1 pre-filled syringe with needle. ${ }^{34}$ From the inspection authorized by the Commission, it was found that the vaccine was available only in a chain of pharmacies where undertaking owned $75 \%$ of the shares. ${ }^{35}$ All other pharmacies that were part of the investigation declared that

\footnotetext{
28 Decision no. 685, dated 18.3.2020 of the Commission of the CA.

29 Decision no. 685, dated 18.3.2020 of the Commission of the CA.

30 Costa-Cabral, F., Hancher, L., Monti, G., Ruiz Feases, F., EU Competition Law and COVID-19, Francisco, p. 11, SSRN Electronic Library, Accessed 9 April 2021.

31 Decision no. 684, dated 18.3.2020 of the Commission of the CA.

32 "CFO Pharma" SHPK, "Delta Pharma - AL" SHPK, "Pharma One" SHPK, "Intermed" SHPK, "Alfarmakos" SHPK, "Trimed" SHPK, "Megapharma” SHPK, "Evita” SHPK, "IMI - Farma” SHPK, "Fufarma” SHA, "Medicamenta" SHPK, "Mini Invest Albania" SHPK, "Delta Med" SHPK, "O.E.S Distrimed" SHPK, "Montal" SHPK, "MSE" SHPK, "Farma Net Albania" SHPK, "Tresi - Farm" SHPK, "Incomed" SHPK, "Florifarma" SHPK, "Lekli" SHPK, "Dial - ALB" SHPK, "Sirol 2008" SHPK, "Aquila Group" SHPK.

33 Decision no. 717, dated 15.10.2020 of the Commission of the CA.

34 Decision no. 715, dated 15.10.2020 of the Commission of the CA.

35 Decision no. 715, dated 15.10.2020 of the Commission of the CA.
} 
their demand for the flu vaccine was refused by the only company that owned the right of distribution. This was the second case where the Commission applied the interim measure during this pandemic, obliging the undertaking to offer to all demanding pharmacies the flu vaccine. ${ }^{36}$

\section{STATE AID AND COVID-19 CRISIS}

In Albania state aid is regulated by the act "On State Aid" ${ }^{37}$ which creates the State Aid Commission and State Aid Directory as bodies that oversee and control state aid. ${ }^{38}$ The State Aid Commission, which is chaired by the Minister of Economy, is the main decision-making authority while the Directory provides the pertinent information to the Commission and makes proposals. ${ }^{39}$ Under this model of organization it is somehow questionable the independence of this body, and the objectivity of its decision-making. ${ }^{40}$ Nevertheless, this issue is not part of this presentation, therefore we will subsequently give an overview of the grants that were approved by the State Aid Commission.

In these paragraphs we will highlight the aids granted by the State Aid Commission (SAC) to reduce the negative effect the initial curfew had on enterprises. After the initial lockdown, no such drastic measures were applied in Albania, but few limitations have been taking place since the relaxation of measures and almost total opening in June 2020.

The state aid was planned as a grant for undertakings and individuals operating in any activity, because unlike future interventions from SAC, the aid given due to the pandemic was distributed to any operating firm meeting the requirements. The government offered two stimulus packages for employees and other categories of unemployed and people receiving economic aid. The first package was approved in March 2020 and started on 1 April 2020 with an extension of no more than three months as of its commencement ${ }^{41}$ and the second package was approved in April and lasted for three months as of its approval. ${ }^{42}$

\footnotetext{
36 Decision no. 715, dated 15.10.2020 of the Commission of the CA.

37 Law no. 9374, dated 21.4.2005, as amended, Official Journal No. 36/2005.

38 Law no. 9374, dated 21.4.2005, as amended, Official Journal No. 36/2005.

39 Law no. 9374, dated 21.4.2005, as amended, Official Journal No. 36/2005.

40 Fjoralba C., Nocioni i Ndihmës Shtetërore që Çrregullon Tregun e Lirë dhe Konkurrencën sipas Legjislacionit dhe Praktikës Ndërkombëtare. 2019, doctoral thesis, [NOCIONI I NDIHMËS SHTETËRORE QË ÇRREGULLON TREGUN E LIRË DHE KONKURRENCËN SIPAS LEGJISLACIONIT DHE PRAKTIKËS NDËRKOMBËTARE - UNIVERSITETI I TIRANËS (unitir.edu.al)], Accessed 13 April 2021, pp. 207 et seq.

41 Decision no. 96, dated 27.3.2020 Authorization of State Aid "COVID-19: Grant Support Scheme".

42 Decision no. 98, dated 28.4.2020 Authorization of State Aid "COVID-19: Grant Support Scheme 2".
} 
The first decision of the SAC lists as beneficiaries the enterprises (physical or legal persons) that exercise a commercial activity with an annual income of 14000 000 ALL (Albanian Lek) (approx. 114000 Euros) and individuals, either being employees in the aforementioned business or unemployed or receiving social assistance. ${ }^{43}$ Whereas the second stimulus package specified as beneficiaries: 1 . Employees of firms with an annual income of 14000000 ALL (Albanian Lek) (approx. 114000 Euros) which had their activities closed during the curfew, 2. Employees of firms with an annual income of 14000000 ALL (approx. 114000 Euros)that were authorized to continue business and 3. Employees of physical persons or legal persons that operate in accommodation facilities. ${ }^{44}$ The latter were granted the right to benefit wage subsidies of 40.000 ALL (approx. 320 Euros).

For businesses, the government offered an aid in the form of two instruments of sovereign guarantee that covered either the interest of the loan or part of the principal. The loans were granted by banks and were designated either for employees' wages or the circulating capital or investments. ${ }^{45}$

\section{EVALUATION OF THE MEASURES OF THE COMPETITION AUTHORITY}

The role of the ACA during this extremely difficult time has been rather inconsistent in handling specific COVID-19 related cases and apathetic as regards handling the overall crisis emerged by the COVID-19. As highlighted above, the ACA has intervened in two cases regarding essential medical products, but only one is directly related with the health emergency crisis caused by COVID-19. The latter, despite taking more than a year for (preliminary and in-depth) investigation is still pending and awaiting decision. The instigation of this investigation was ignited by the good aim to protect consumers from unscrupulous business which exploit this crisis to maximise their profits. But despite this good aim, the ACA has not been active to timely decide on this issue. Consumers are still suffering the effects of the opportunistic behaviour of undertakings operating in the medical supply market. Yet, there are numerous reports in the social media for extremely high prices consumers are facing especially in the health sector, either for specific medications or health services.

Decision no. 96, dated 27.3.2020 Authorization of State Aid "COVID-19: Grant Support Scheme". Decision no. 98, dated 28.4.2020 Authorization of State Aid "COVID-19: Grant Support Scheme 2". Ministria e Financave dhe Ekonomisë, [Ministria e Financave dhe Ekonomise], Accessed 13 April 2021. 
However, when assessing the intervention of the ACA, it is noteworthy to highlight that, unlike many other competition authorities in other jurisdictions that are designated to safeguard competition and oversight the market, in Albania the CA has only the competence to monitor the correct implementation of the provisions of the Act "On the Protection of Competition". ${ }^{46}$ Consequently, the market conducts that do not constitute an anticompetitive behaviour do not fall within the ambit of the ACA activity. There are other structures created by the legal framework that could have handled this issue properly. For example, the Consumer Protection Commission (CPC) created by the act "On consumer protection" ${ }^{7}$ which is the body designated to deal, amongst others, with unfair contract terms and apply the relevant sanctions. ${ }^{48}$ Another structure, that is the State Inspectorate for Market Surveillance (SIMS), is created to monitor the market and safeguard consumers' rights but only as regards products safety and intellectual property rights. ${ }^{49}$ Given this background, the specific behaviour of the market participant at issue, does not fall within the competence of the SIMS, but rather under the ambit of the $\mathrm{CPC}^{50}$. However, the latter may initiate investigations based on consumers complaints or in cooperation with other structures that exercise market surveillance (such as SIMS). ${ }^{51}$ Basically, the SIMS should have signalised the CPC to intervene and investigate what was happening with the market and consumers. ${ }^{52}$

When assessing the ACA decisions, one may normally raise the question: which is the anticompetitive behaviour that the ACA has sanctioned in this case: is it abuse of dominant position or an agreement between competitors?

46 Article 24 of the Act no. 9121, dated 28.7.2003 "On the protection of competition", as amended, Official Journal No. 71/2003.

47 Article 52 of the Act “On Consumer Protection", nr. 9902, dated 17.4.2008, Official Journal 61/2008, as amended.

48 Dollani, N., Ligji për Mbrojtjen e Konsumatorëve: Teksti me Shpjegime, Pegi, 2018, pp. 445-448.

49 Established through the Decision of the Council of Ministers no. 36, dated 20.1.2016 "On the establishment, organisation and functioning of the State Inspectorate for Market Surveillance"

50 Even though this issue is debatable, given the specific conditions imposed by the pandemic (the extreme need for consumers to purchase these products), the CPC should have intervened, despite the fact that it was an essential contract term and according to the law, these terms are not included in the list of unfair terms. See Dollani, N. Op. Cit, Fn, 48, pp. 151-153.

51 Dollani, N. Op. cit., Fn 48, p. 446

52 Another viable alternative to handle this market situation may have been to engage the tax authorities to implement the provisions of the Normative act that precluded undertakings to set higher prices for the medical products during the state of health emergency. These authorities may have applied the fines as stipulated in the normative act either through direct inspection or through the complaint received by other state bodies. 
Certainly, there was abuse that was reflected in the market, but did it stem from the conduct of the firms altogether or was it a mere parallel of interest? In this light, it would be useful to dwell into a discussion on the how the shortage during the pandemic reflected into the market a distorted competition.

In the decision that the ACA applied the temporary measure, does not indicate in which anticompetitive behaviour the undertakings were involved. One can assume that it was abuse of dominant position, but can 27 undertakings altogether be at the same time in a dominant position in a relevant market? This seems highly unlikely.

It is true that European courts (CFI and ECJ) have asserted in several cases ${ }^{53}$ the concept of joint/collective dominance. To ascertain that this was the form of abuse (by the aforementioned firms) few criteria must be fulfilled. Firstly, to conclude that a collective dominance has taken place, a common/joint policy that is implemented by all the undertakings concerned must exist. ${ }^{54}$ It is clear from the conduct of the undertakings concerned that they are applying high prices for essential products, but this reflects the shortage that is felt in the market. They are merely oriented towards higher profits, taking advantage of the pandemic and this line of action does not require any coordination between them. Was this conduct abusive? Yes! But was it a form of economic strength that led to this abusive behaviour or was it just a conduct oriented towards higher profits at any cost? More likely, the latter. To prove that a collective dominance occurred in the market, the links between the firms must be confirmed and that these links allowed them to act independently of law pressures of competition ${ }^{55}$. Can just the shortage of some goods in the relevant market that lead the firms to set higher prices be considered a link between these independent undertakings? Obviously, it cannot be considered as such.

Secondly, the common policy must be sustainable over time. ${ }^{56}$ Again this is not the case for the undertakings at issue, because as soon as the market was normally supplied with alcohol, face masks and disinfectant gels, the prices of these products returned to a more normal range.

Apparently (without the full investigation being disclosed), when analysing the characteristics of the collective dominance, we reach the conclusion that the concerned undertakings do not form a collective dominance.

53 Such as: Compagnie Maritime Belge Transports SA, Compagnie Maritime Blege Sa and Dafra-Lines A/S v. Commission [2000] ECR I-1356, Case 22/71 Beguelin Import G.L. Import Export [1971 ECR 949], French Republic and others v. Commission [1998] ECR I-1375.

54 DG Competition discussion paper on the application of Article 82 of the Treaty to exclusionary abuses, pg. 48

55 Dabbah, Maher M., EC and UK Competition Law, Cambridge University Press, 2004, p. 592.

56 Ibid., pg. 49. 
Likewise (given the lack of the factual background), this behaviour could not constitute an agreement, because it was necessary for the ACA to have enough evidence that the undertakings concluded an agreement or were behaving according to a common understanding. Given this background, we may conclude that this measure applied by the ACA raises questions upon its legality.

Furthermore, as regards the overall management of the crises, taking the examples of other competition authorities the ACA did not adapt the current market condition with more relaxed competition rules such as for example to allow some necessary forms of cooperation especially in the health care sector or the pharmaceutical industry. Currently there are no clear guidelines as regards the behaviour of undertakings that may be excluded from the scope of application of the provisions of the competition law. Unlike other competition authorities such as Competition and Market Authority (in the UK) and Communication form the Commission ${ }^{57}$ that have set clear criteria when undertakings may be exempted from competition rules, unfortunately no such action has been taken from the ACA. ${ }^{58}$ Certainly, this does not mean that companies may have the right to ignore any competition rules, but to balance the extraordinary situation with the need to protect the market and consumers.

Given the lack of intervention form the ACA, domestic undertakings were not, and we assume are still not clear which form of cooperation between them may be exempted from the application of the competition regulatory framework.

In this background, it would have been useful and transparent for undertakings to have a better view of cooperation initiatives that do not fall within the ambit of the competition law, under the new conditions imposed by the state of health emergency. Therefore, a reference to the standards set in the Communication of

$57 \quad$ Temporary Framework for assessing antitrust issues related to business cooperation in response to situations of urgency stemming from the current COVID-19 outbreak, C $116 \mathrm{I} / 7$, dated 8.4.2020, OJ C 116I, 8.4.2020, pp. 7-10.

58 For example as those set by the he CMA, which state that the latter will not take enforcement action if temporary measures are taken by business to coordinate actions when: "(a) are appropriate and necessary in order to avoid a shortage, or ensure security, of supply; (b) are clearly in the public interest; (c) contribute to the benefit or wellbeing of consumers; (d) deal with critical issues that arise as a result of the COVID-19 pandemic; and (e) last no longer than is necessary to deal with these critical issues,". CMA approach to business cooperation in response to coronavirus (COVID-19) [CMA approach to business cooperation in response to coronavirus (COVID-19) - GOV.UK (www.gov.uk)], Accessed 13April 2021. The Italian Competition and Market Authority, [AGCM - Autorita' Garante della Concorrenza e del Mercatol, Accessed 13 April 2021; or the Temporary Framework for assessing antitrust issues related to business cooperation in response to situations of urgency stemming from the current COVID-19 outbreak. 
the Commission and the other national competition authorities would have been helpful for market operators. ${ }^{59}$

Also, the ACA has not indicated any contact point where the companies can seek advice whether a certain behaviour in the market can be sanctioned or may be exempted from the application of the legal framework or where consumers may directly address concerns regarding abusive behaviours. It would have been beneficial in the light of certainty and predictability for the market and especially undertakings to have clear boundaries where they can extend cooperation.

In this background, the establishment of a task force that could handle COVID-19 crisis would have been a good tool to deal with undertakings enquiries as regard the legality of their conduct. Some competition authorities around the world have created similar structures. ${ }^{60}$

\section{CONCLUSION}

Given the analyzation of the measures and the role of the Albanian CA, we may conclude that:

First, the ACA should have taken e more active role in managing the crisis caused by COVID-19. That entails the obligation of the Albanian CA to protect consumers and undertakings as well. This may have been accomplished via providing timely intervention in the market and providing guidelines for undertakings. It is the first time that Albanian market faces this emergency. The Albanian competition authority is relatively a new body and lacks the excessive experience to deal with situation of crises. Other national competition authorities may have handled other market crisis, such as the financial crisis, thus their approach may have been followed.

59 Temporary Framework for assessing antitrust issues related to business cooperation in response to situations of urgency stemming from the current COVID-19 outbreak, C $116 \mathrm{I} / 7$, dated 8.4.2020, pp. 12, OJ C 116I, 8.4.2020, pp. 7-10. a. Coordinate joint transport for input materials; b. Contribute to identifying those essential medicines for which, in view of forecasted production, there are risks of shortages; c. Aggregate production and capacity information, without exchanging individual company information; d. Work on a model to predict demand on a Member State level, and identifying supply gaps; e. Share aggregate supply gap information, and request participating undertakings, on an individual basis and without sharing that information with competitors, to indicate whether they can fill the supply gap to meet demand (either through existing stocks or increase of production). Se also, the Italian Competition Authority announcement, [AGCM - Autorita' Garante della Concorrenza e del Mercato], Accessed 13 April 2021.

60 Costa-Cabral, F., Hancher, L., Monti, G., Ruiz Feases, F., EU Competition Law and COVID-19, Francisco, SSRN Electronic Library pp. 12, Accessed 9 April 2021. 
Second, a contact point for receiving all complaints from consumers and undertakings should have been designated and furthermore a specific task force to timely handle these cases should have been created. This did not require major structural organization, but prioritizing cases and fuel the structure with the necessary resources to timely handle competition issues.

Finally, we conclude that a more vigorous approach should have been taken from the Albanian Competition Authority to inform consumers and companies.

\section{REFERENCES}

\section{BOOKS AND ARTICLES}

1. Caka, F., Nocioni i Ndihmës Shtetërore që Çrregullon Tregun e Lirë dhe Konkurrencën sipas Legjislacionit dhe Praktikës Ndërkombëtare, Tirana, 2019, doctoral thesis.

2. Dabbah, M. M., EC and UK Competition Law, Cambridge University Press, 2004.

3. Dollani, N. Ligji Për Mbrojtjen e Konsumtaroëve: Teksti me Shpjegime, Pegi, 2018.

4. Malltezi, A.; Rystemaj, J.; Pelinku, L., Aspekte të së Drejtës së Biznesit në Shqipëri, Tiranë, Mediaprint, 2013.

\section{COURT OF JUSTICE OF THE EUROPEAN UNION}

1. Case T-24/93 (Joint cases T-25/93) Compagnie Maritime Belge Transports SA, Compagnie Maritime Belge Sa and Dafra-Lines A/S v. Commission [2000] ECR I-1356,

2. Case C-22/71 Beguelin Import G.L. Import Export [1971 ECR 949],

3. Case C-68/94, French Republic and others v. Commission [1998] ECR I-1375.

\section{EU LAW}

1. Temporary Framework for assessing antitrust issues related to business cooperation in response to situations of urgency stemming from the current COVID-19 outbreak, [2020/C] 116 I/02, OJ C 116I, 8.4.2020, pp. 7-10.

\section{LIST OF NATIONAL REGULATIONS, ACTS AND COURT DECISIONS}

1. Civil Code, Law no. 7850, dated 29.7.1994, Official Journal No. 11,12,13,14/1994; as amended by act no. 8536, dated 18.10.1999, Official Journal No. 29/1999; Act no. 8781, dated 3.5.2001, Official Journal No. 24/2001; Act no. 17/2012, Official Journal No. 18/2012; Act no. 121/2013, dated 18.4.2013, Official Journal 67/2013, Act no. 113/2016, Official Journal No. 219/2016.

2. Act no. 8044, dated 7.12.1995 “On Competition”, Official Journal No. 27/1995.

3. Act no. 9121, dated 28.7.2003 "On the Protection of Competition", Official Journal No. 71/2003, as amended by Act no. 9499, dated 3.4.2006, Official Journal No. 37/2006; Act no. 9584, dated 17.7.2006, Official Journal Act no. 10317, dated 16.9.2010, Official Journal No. 135/2010. 
4. Act "On Consumer Protection", nr. 9902, dated 17.4.2008, Official Journal 61/2008, as amended by Act no. 10444, dated 14.7.2011 Official Journal 103/2011; Act no. 15/2013, Official Journal 29/2013, Act no. 71/2018, Official Journal 162/2018.

5. Normative Act no. 3, dated 15.3.2020, Official Journal No. 37/2020.

6. Decision of the Council of Ministers no. 36, dated 20.1.2016 "On the establishment, organisation and functioning of the State Inspectorate for Market Surveillance", Official Journal $10 / 2016$.

7. Decision no. 684, dated 18.3.2020 of the Commission of the CA.

8. Decision no. 685, dated 18.3.2020 of the Commission of the CA.

9. Decision no. 716, dated 15.10.2020 of the Commission of the CA.

10. Decision no. 717, dated 15.10.2020 of the Commission of the CA.

11. Decision no. 715, dated 15.10 .2020 of the Commission of the CA.

12. Decision no. 96, dated 27.3.2020 Authorization of State Aid "COVID-19: Grant Support Scheme".

13. Decision no. 98, dated 28.4.2020 Authorization of State Aid "COVID-19: Grant Support Scheme 2".

\section{WEBSITE REFERENCES}

1. Annual Report of the Competition Authority, 2006, [report_shqip_ndarje ngjyre.indd (caa. gov.al)], pp. 10, Accessed 9 March 2021.

2. Annual Report of the Competition Authority, 2019, [AK-Raporti-Vjetor-2019-Permbledhje-Ekzekutive.pdf (caa.gov.al)], Accessed 8 March 2021.

3. Albania: Health officials confirm first cases of COVID-19 March 9 [garda.com], Accessed 9 March 2021.

4. CMA approach to business cooperation in response to COVID-19, 25 March 2020, CMA 118 [CMA approach to business cooperation in response to coronavirus (COVID-19) GOV.UK (www.gov.uk)], Accessed 13 April 2021.

5. Antitrust: Joint statement by the European Competition Network (ECN) on application of competition law during the Corona crisis, [https://ec.europa.eu/competition/ecn/202003 joint-statement_ecn_corona-crisis.pdf], Accessed 13 April 2021.

6. Costa-Cabral, F., Hancher, L., Monti, G., Ruiz Feases, F., EU Competition Law and COVID-19, [SSRN Electronic Library]. Accessed 9 April 2021.

7. Ministria e Financave dhe Ekonomisë [Ministria e Financave dhe Ekonomise], Accessed 13 April 2021.

8. DG Competition discussion paper on the application of Article 82 of the Treaty to exclusionary abuses, Brussels 2005, [https://ec.europa.eu/competition/antitrust/art82/discpaper2005.pdf], accessed 20.6.2021.

9. The Italian Competition Authority [AGCM - Autorita' Garante della Concorrenza e del Mercato], Accessed 13 April 2021. 